Covered in: Web of Sciences (WOS); EBSCO; ERIH+; Google Scholar; Index Copernicus; Ideas RePeC; Econpapers; Socionet; CEEOL; Ulrich ProQuest; Cabell, Journalseek; Scipio; Philpapers; SHERPA/RoMEO repositories; KVK; WorldCat; CrossRef; CrossCheck

2018, Volume 9, Issue 4, pages: 54-64 | doi: https://doi.org/10.18662/po/45

\section{Theological Ideas of Nichifor Crainic and their Relevance for His Political Activity}

\section{Iuliu-Marius MORARIU1}

${ }^{1} \mathrm{PhD}$. Candidate, Faculty of Orthodox Theology, "Babeş-Bolyai" University, ClujNapoca, Romania. E-mail: maxim@radiorenasterea.ro. Phone: 0751690149 .
Abstract: Important and, in the same time, controversial personality of interwar period and the later one, Nichifor Crainic was in the same time poet, theologian, philosopher and politician. He published many articles, book reviews, chronicles, meditation and theological studies in books and journals like Gândirea or Ramuri (the first one founded by him). In the same time, he was the first professor of mystical theology in a Romanian Faculty of Theology, the one of Bucharest. His theological ideas are still relevant today for the theological space and this make them to be analysed, referred to and quoted. In the same time, some of them have influenced his political attitude, making them to become exponential for Romanian Nationalism during the interwar period, to see, as others (for example Nae Ionescu) of being Orthodox as linked with national identity, and also to be closed with far-right movement during the aforementioned period, but also during the Second World War. Using his ideas expressed, both in his books of poetry or theology or in journals like the ones already named, but also information from the books and articles dedicated to him, we will try there to see how his theological ideas and the influence of theology and Orthodox Church upon him, have influenced the Romanian writer in his political actions. We will also see how his ideas are reflected in his work as politician and writer and we will analyse the influence that he had upon other personalities of his time with same concerns and political orientation. The research will therefore bring again into attention the profile and work of the Romanian theologian, offering a new approach of the relationship between his ideas and works and a reevaluation of his ideas and their actuality.

Keywords: theology; interwar period; Legionary Movement; Gândirea journal; Christianity;

How to cite: Morariu, I.-M. (2018). Theological Ideas of Nichifor Crainic and their Relevance for His Political Activity. Postmodern Openings, 9(4), 54-64.

https://doi.org/10.18662/po/45 


\section{Introduction}

In Romanian Theological space, but also in the national culture of this country, Nichifor Crainic is an author still debated and investigated. His ideas, published in journals like Gândirea (Morariu, 2015: 29-32) or in his books (Crainic, 1941a), are still interesting and important. They transform him in an important writer, but also in a controversial personality and make him to be quoted and valorised especially in the first domain of them (Căşvean \& Morariu, 2015: 56-70; Morariu \& Căşvean, 2016: 281-289). Philosophers, historians, philologists or other scholars who wrote about nationalism, its roots and about the dissolution of the nationalism in postmodernity (Foucault, 1989), could find for sure, in his work and ideas, information about the way how this topic can be founded and has particularities in Romanian space, while the investigation of his work will help for sure authors like Mattei Dogan to understand why the decline of nationalisms within Western and Eastern Europe took place in the $20^{\text {th }}$ century (Dogan, 1994: 281-305).

Despite of that, there are still many aspects of his life, activity or teaching that can be emphasized and presented in a new manner, or just put into attention. For example, his qualities as a memoirist (Crainic, 1991) are, in our opinion, not enough investigated, while his poetical books (Crainic, 1929a, 1998) and their message, structure and relevance can also be read in new keys.

Noticing all there, we will try to to bring into attention his theological ideas and to see how they have influenced his political way of thinking and acting, because, he was not only a theologian, a poet and writer, but also a politician in a very difficult period of Romanian history and this fact contributed to his portrait as controversial man. Because of the expected dimensions of this research, we will not present here his biography in detail - therefore, the readers interested on this aspect are invited to see, for example Ică (2018: 7-22), but we will focus on the historical moments that are important for our problem. We will use both his books, studies and articles, but also the monographs and other texts dedicated to him. All the information will be investigated according to the analytic-deductive method, but we will not neglect the use of other methods when we consider that this fact will be necessary. 


\section{Theological ideas of Nichifor Crainic and their relevance for his political activity}

Before starting this presentation, we consider important to say that, when somebody wants to speak about the theological ideas of Nichifor Crainic, he must not limit his presentation only to his theological, books, articles and reviews on theology, but to try to see his entire publicist work. It is true that the quintessence of his thinking can be founded in these texts and that, as the first professor of mystical theology from Romanian Orthodox space (Căşvean, 2015: 46), the philosopher will present in his lectures and books on this topic (Crainic, 1993; 2010a, 2010b), his ideas about the most relevant mystics from Christian spirituality and will try to link them and their ideas with personalities from the autochthon space, but in the same time, in poems like: The song of the chalice (Crainic, 1990: 101-102) and many others, there can be found very interesting theological ideas. Moreover, sometimes, the author releases a theological idea in a literary fragment, and later he develops it in a theological research.

A general and brevilocvent summarizing of his theological way of thinking will underline the fact that the entire theology of the aforementioned philosopher is centred on the man. Starting, like in Nellas case from the anthropological problem (Nellas, 2009), he goes, like him to the soteriological solution to it (Nellas, 2012). Conscious of the fact that, as father Dumitru Stăniloae (2003: 103) shows: "man is a theandrinc (divine and human) being", he speaks about the purpose of human being and the way how he can be fulfilled in Christ and through the Church. In the same time, he sees the general aspects of the spirituality as being deeply linked with the local aspects of tradition and history. His ideas from Orthodoxy and etnocracy (Crainic, 1997) are relevant in this sense. In fact, this idea of linking Orthodoxy with national identity, which will lead him to nationalism, is one of the most important ones linked with our topic.

Born in his poetries from the period before 1918, it is a way of thinking that it has been not something strange or unique in the interwar landscape. Moreover, this will put him in contact with writers and philosophers like Nae Ionescu (Albu, 1993: 411-416; Iloaie, 2003; Petreu, 2016), making him to be a really "fashionable" thinker of those times. Like others, he will say that being Romanian means to be also Orthodox and will speak about the spiritual nobility given to the Romanian people by the 
Orthodoxy (Crainic, 2003a: 26). He will use this to militate for the rebirth of national conscience.

But, if during the interwar period, he will use this rather as a theoretical approach, later, during the war, when he becames politician and minister of Romanian propaganda, he will slip in a practical way, to the nationalism. In one article from that period, he will say about this:

"Nationalism is the elementary condition of the renaissance of all peoples, while its absence is the sign of decadence and death." (Crainic, 2003a: 49; 1935: 113-116).

In a very predictable way, this will lead him close to the legionary doctrine and later to the Nazis one. Therefore, in the beginning of the war, he will write in the journal founded by him about the legionary revolution (Crainic, 1940: 521-525), or to praise Adolf Hittler (Crainic, 1941b: 337-340). At the basis of all these extremist ideas linked to the far-right movement, there are some of his theological ideas and convictions.

But Crainic was not only a legionary militant and a writer with a very deep theological base, very respected. As professor, from 1926, at the Faculty of Orthodox Theology from Chişinău, he will teach, at the beginning of the period, religious literature and later, he will become, the first Romanian professor of Orthodox Mystique (Căşvean, 2015: 49). About this period of his life and its relevance, a contemporary theologian shows that:

"Also in 1926, Crainic become Professor at the New Faculty of Theology from Chişinău, created at the initiative of the Ministry of Culture, the philosopher Ion Petrovici (1782-1972). For six years, he will travel with regularity from Bucharest to Chişinău, where he was teaching modern religious literature. The famous lecture about "Dostoievski and Russian Christianity," was the literary introduction to the class of "Elements of Orthodos Mystique," where, under the clothes of literature, Crainic will impose the first class of Orthodox Mystique at the faculties of Orthodox Theology - a Romanian priority from the superiour schools of theology from panorthodox space." (Ică, 2018: 10).

There, as a professor of Mystique, where he was the one who contributed at the rediscovering of this topic in Orthodox spirituality (Ică, 2018: 5), fact that will determinate also other faculties to invite him to provide inaugural lectures (Crainic, 2010a: 5-14), he focused in his lectures and articles on the philocalic literature and the one of later mystics from Catholic and Protestant space. Therefore, he investigated the way how the spiritual road of the man to divinity could be influenced by ascetic life, revelations and visions and he wrote about the important personalities of the genre, their ideas ant their influence upon Christian spirituality. This is the 
reason why, in his treaties of mystique (Crainic, 1993, 2010b), he will be intensely concerned with the teaching coming from the evil, the monastic spirituality, or other aspects that speak about the ways of deepening the relationship with Christ and becoming a good Christian and a self-developed man. Some of his ideas from this theological works will be later developed in his poetries, because in Crainic's work, all the domains are linked between them and the idea presented in one of them is often developed in another one (Crohmălniceanu, 1974: 311).

A special contribution of Crainic to the topic will be the way how he understood, in some situations, the mystique in the local and national context. Dostoievski (Ică, 2018: 10) and Eckhart (Crainic, 2010a: 10), are eloquent examples of this fact. Most probably, this had determinated him to plead for an understanding of Orthodox spirituality in national context. And this will constitute the element that will create the link to the legionary taught and make him later to be seen as closer to Nazi ideology, because of his nationalist view (Crainic, 1935: 113-116).

In the same time, by linking politics with Orthodoxy (Crainic, 1923: 77-83; Morariu, 2018: 153-157), and speaking about the relevance of elitism in theology, he will go, step by step to the anty-Semitism, which will have biblical fundaments like in the two already aforementioned political ideologies. But, for him, there will be also another reason that will determinate sometimes the fight with other cultures: the need to preserve the own culture. Crainic will often write about this topic, especially in his articles from Gândirea (Crainic, 1928a: 307-310, 1928b: 76-77, 1929b: 1-11). In this case, it will be not a specially-directed anty-Semite attitude, but an attitude of protest against French, English and even Russian or Turkish influences from our culture and the contemporary trends that were bringing to them.

Of course, sometimes attitudes about the necessity of internationalist pacifist attitude (Crainic, 1930: 101-105), that will seem almost contradictories with the nationalist ones will be also part of his way of thinking and will have theological fundaments, because, as it has been already mentioned, in his work, the domains and topics are linked and the theological ideas are often developed using philosophical arguments or poetry, for having an easier dissemination of the message and in order to make him to be up to nowadays used and quoted both in books of history (Hitchins, 1994: 303-312) and philosophy.

It would be for sure wrong to say that the theological conceptions of the philosopher constitute the basis of his far-right ideas. Indeed, sometimes, arguments for some of his ideas can be found-there, like the 
anty-Semite ones, but it must be said that in this case, during the Second World War and even before, in Romanian space there were a few writers interested in history, philosophy, theology and other domains too, who were also developing such a conception without being linked with Nazi ideology (Boşca-Mălin, 1943), and some of them, even not with the legionary one. On the other side, it is difficult to say how much he was linked with the aforementioned ideologies without taking into account a few aspects. Therefore, it must be said that although there were a few texts on antiSemite topic written during the interwar period (Crainic, 1941a), their number increased very much especially after his election as a minister of propaganda during the war. On the same time, the fact that he had censored his memorials during the communist period (Crainic, 1991), hoping that he will be allowed to publish it, it also makes today difficult a realist evaluation of his attitude and thought. Therefore, it must be said that, some of his ideas were close to Nazi ideology and to the legionary one, but in the same time, he didn't take a very clear position neither had he a practical political plan or action in this sense. Personally, we think that he has been rather linked with nationalism and autochthon elements from Romanian culture and this made him to be close to far-right movement, he was not a convinced anti-Semite, or a follower of Nazi ideology, but rather a member of a cultural direction to which writers and philosophers like Nae Ionescu were belonging too.

As a philosopher, Crainic is important not only because of his relationships with important personalities of his time with people like Eliade or Cioran or for his ideas about the possible interactions between philosophy and theology (Ică, 2018: 10), that make him to be known and quoted also in postmodern times, especially in the theological space, but also because of some points where he really interacts with their way of thinking. The fact that he writes in 1937 about the necessity of a "change of the face of Romania" (Crainic, 1937: 12), that will later define a project of Cioran (Cioran, 1936), greeting a project of the philosopher that will be later developed by him in the exile, proves his visionary qualities. Also, by promoting a new spirituality (Hasmațuchi, 2011: 57-59), that it is not only based on the ideas like nationalism, but also on ascetic practices, revival of mystical spirituality and valorisation of local cultural and spiritual heritage from Romanian space, he became an important voice of the philosophy and spirituality of his times, but also of the future ones. Therefore, he will not influence then only Constantin Rădulescu Motru (1928: 42), but also Eliade (1928: 47), who will later contribute to the dissemination of his ideas up to postmodern era, but also some of the contemporary philosophers (Dur, 2007: 26-31). 
Therefore, it can be mentioned that, although he was a modern philosopher because of the time where he lived and his ideas, he is also important for the postmodern space thanked to ideas like the aforementioned one, developed by other thinkers who were influenced by him. Of course, his theological background and way of thinking are also very important and contribute to the articulation of his ideas.

\section{Conclusion}

As we have already tried to show in our presentation, in Nichifor Crainic, theological ideas are, in most of the situations, linked with the Orthodox mystique (Ică, 2018: 10-12). As a teacher of this topic in University, but also as a philosopher deeply influenced by German mystique, he tried to bring this domain in Romanian space and make it important for the theological space and he was successful.

Of course, his personal note on this domain, where he was one of the pioneers of interdisciplinary research in the space where he activated, because of linking literature, philosophy, history and theology (Căşvean, 2015: 49; Morariu, 2015: 29), was to militate for the understanding of local contributions to the development of the topic and its attempt to create an understanding of mystique from Romanian space linked with tradition. This was also the element that makes him to use sometimes his theological ideas to fundament anti-Semite attitudes or to become closer to the far-right movement from the Romanian and German spaces, without making very clear if he was really an adept of the Nazi doctrine or of the legionary one in all its aspects. Also, makes him to be also important in postmodern space, where his ideas are used, quoted and debated both by theologians, philologists, historians or philosophers. The self-censorship of memorial works makes also difficult to analyse this topic and to see its real undergrounds. But, despite of these aspects, some of his important ideas like his Eucharistic view (Căşvean \& Morariu, 2015: 56-70; Crainic, 2010a: 5-14), are still important for contemporary theology and in use and this make him an important personality that must be rediscovered and emphasized in a realistic way, with his big contributions and his minuses too.

\section{Acknowledgment}

Work realized in the project: "Tolerance and intolerance in Nichifor Crainic's publicistic work / aspects of theology, history and actuality," under the coordination of "Diatheke" Foundation of "Babeş-Bolyai" University, Cluj-Napoca, Romania 


\section{References}

Albu, G. (1993). Nae Ionescu - filosof şi practician al educaţiei [Nae Ionescu philosopher and practician of education]. Revista de filosofie, 40(4), 411-416.

Boşca-Mălin, E. (1943). Evreii in țara Năsăudului [Jews in Năsăud county]. Braşov, Romania: Editura „Asociației Scriitorilor şi Gazetarilor Năsăudeni”.

Căşvean, E. (2015). Nichifor Crainic and the Romanian Orthodox Mystique. Astra Salvensis, 5(suppl. 1), 46-52. Retrieved from:

https://www.researchgate.net/publication/311639896_Nichifor_Crainic_a nd_the_Romanian_orthodox_mystique

Căşvean, E. I., \& Morariu, I. M. (2015). Nichifor Crainic's eucharistic view reflected in his poetic and philosophical work. European Scientific Journal, 26(11), 5670. Retrieved from: https://eujournal.org/index.php/esj/article/view/6230/6056

Cioran, E. M. (1936). Schimbarea la față a României [The change of the face of Romania]. Bucharest, Romania: Vremea.

Crainic, N. (1923). Politică și ortodoxie [Politics and Orthodoxy]. Gândirea, 28, 7783.

Crainic, N. (1928a). Spiritualitate [Spirituality]. Gândirea, 92, 307-310.

Crainic, N. (1928b). Tradiție şi internaționalism [Tradition and internationalism]. Gândirea, 86, 76-77.

Crainic, N. (1929a). Darurile pământului - poęii [The gifts of the earth - poems]. (3rd ed.). Bucharest, Romania: Cartea Românească.

Crainic, N. (1929b). Sensul tradiției [The sense of tradition]. Gândirea, 109-110, 1-11. Retrieved from: https://www.crestinortodox.ro/religie/sensul-traditieinichifor-crainic-69579.html

Crainic, N. (1930). Pacifism. Gândirea, 124, 101-105. Retrieved from: http://documente.bcucluj.ro/web/bibdigit/periodice/gandirea/1930/BC UCLUJ_FP_279479_1930_010_004.pdf

Crainic, N. (1935). Naționalitatea în artă [Nationality in art]. Gândirea, 14(3), 113116. Retrieved from: http://miscarea.net/gandirea-nationalitatea.htm

Crainic, N. (1937). Schimbarea la faţă a României [The change to the face of Romania]. Gândirea, 16(2), 12-15.

Crainic. N. (1940). Revoluția legionară [Legionary revolution]. Gândirea, 19(8), 521525. Retrieved from: http://miscarea.net/crainic-revolutia-legionaragandirea.htm

Crainic, N. (1941a). Germania şi Italia în scrisul meu de la 1931 incoace [Germany and Italy in my writings since 1932]. Bucharest, Romania: Cugetarea. 
Crainic, N. (1941b). Aliații lui Adolf Hittler [Adolf Hitler's allies]. Gândirea, 20(7), 337-340. Rterieved from:

http://documente.bcucluj.ro/web/bibdigit/periodice/gandirea/1941/BC UCLUJ_FP_279479_1941_020_007.pdf

Crainic, N. (1990). Şoim peste prăpastie. Versuri inedite create în temniţele Aindului [Hawk over the gulf. Unpublished poems composed in Aiud carcel]. Bucharest, Romania: Roza Vânturilor.

Crainic, N. (1991). Zile albe, qile negre. Memorii [White days, black days. Memories]. Buaharest, Romania: Gândirea Publishing House.

Crainic, N. (1993). Sfințenia - implinirea umanului (Hollines - the fulfilness of Human). Iaşi, Romania: Editura Mitropoliei Moldovei şi Bucovinei.

Crainic, N. (1997). Ortodoxie si etnocratie [Orthodoxy and etnocracy]. Bucharest, Romania: Albatros.

Crainic, N. (1998). Poezii [Poems]. Bucharest, Romania: 100+1 Gramar.

Crainic, N. (2003a). Rasă şi religiune [Race and religion]. In: R. Codrescu (Ed.), Fiecare in rândul cetei sale. Pentru o teologie a neamului [Each one as part of his team. For a theology of nation] (pp. 48-66). Bucharest, Romania: Christiana.

Crainic, N. (2010a). Curs de Mistică germană. Meister Eckhart şi şcoala sa (19361937). Prelegerea I - inaugurală [Lecture of German mystique. Meister Eckhart and his school (1936-1937). First lecture - inaugural]. Tabor, 34(10), 5-14. Retrieved from: http://www.taborrevista.ro/in_ro.php?module $=$ content_full\&id $=10587$

Crainic, N. (2010b). Cursurile de mistică - teologie mistică, mistică germană [Mystical lectures - mystical theology, German mystique]. Sibiu, Romania: Deisis.

Crohmălniceanu, O. S. (1974). Literatura română între cele două Ră̧̊boaie Mondiale [Romanian literature between the two World Wars]. (2 ${ }^{\text {nd }}$ vol.). Bucharest, Romania: Minerva Press.

Dogan, M. (1994). The Decline of Nationalisms within Western Europe. Comparative politics, 26(3), 281-305. Doi:10.2307/422113

Dur, I. (2007). Cariatide. Sibiu, Romania: Psihomedia.

Eliade, M. (1928). Noua spiritualitate [The new spirituality]. Tiparniţa literară, 30(2), 47-50.

Foucault, M. (1989). The Archaeology of Knowledge. London, UK: Routledge.

Hasmațuchi, G. (2011). Nichifor Crainic and the interwar "New Spirituality". Philosophy, Social and Human Disciplines, 2, 57-59. Retrieved from: http://www.apshus.usv.ro/arhiva/2011II/004.\%20pp.\%2057-69.pdf

Hitchins, K. (1994). Romania 1866-1947. Oxford, UK: Oxford University Press. 
Ică, I. (2018). Nichifor Crainic. Revista Teologică, 111(2), 7-22. Retrieved from: http://www.revistateologica.ro/wp-content/uploads/2018/02/1.Nichifor-Crainic.pdf

Iloaie, Ş. (2003). Nae Ionescu şi ortodoxia românească [Nae Ionescu and Romanian Orthodoxy]. Cluj-Napoca, Romania: Limes.

Ioan, I. jr. (2010). Nichifor Crainic şi redescoperirea misticii în Ortodoxie în prima jumătate a secolului XX [Nichifor Crainic and the rediscovery of mystique in Orthodoxy in the first half of the 20th century]. In: I. Ică jr. (Ed.), Nichifor Crainic, Cursurile de mistică [Nichifor Crainic, classes of mystique] (pp.3-77). Sibiu, Romania: Deisis.

Morariu, I. M. (2015). Nichifor Crainic şi "Gândirea" [Nichifor Crainic and 'The taught"]. Tabor, 9(3), 29-32.

Morariu, I. M. (2018). An Orthodox perspective on political theology. Journal for the Study of Religions and Ideologies, 49, 153-157. Retrieved from: http://jsri.ro/ojs/index.php/jsri/article/view/925/756

Morariu, I. M., \& Căşvean, E. I. (2015). Tinerețea sufletească şi importanța ei în gândirea lui Nichifor Crainic [The youth of the soul and its relevance in the taught of Nichifor Crainic]. In: M. Himicinschi (Ed.), Young People in Church \& Society (pp.281-289), Proceedings of $15^{\text {th }}$ International Symposium on Science, Theology and Arts (ISSTA 2016). Alba-Iulia, Romania: Reîntregirea.

Nellas, P. (2009). Omul - animal îndumnezeit - perspective pentru o antropologie ortodoxă [Man - divinised animal - perspectives for an Orthodox anthropology] (4rd ed.). Sibiu, Romania: Deisis.

Nellas, P. (2012). Hristos, dreptatea lui Dumnezeu şi îndreptarea noastră - pentru o soteriologic ortodoxă [Christ, God's justice and our salvation - for an orthodox soteriology]. Sibiu, Romania: Deisis.

Petreu, M. (2016). Diavolul și ucenicul său: Nae Ionescu - Mibail Sebastian [The evil and his disciple: Nae Ionescu - Mihail Sebastian]. (3d. ed.). Iaşi, Romania: Polirom.

Rădulescu-Motru, C. (1928). Noua spiritualitate [The new spirituality]. Tiparniţa literară, 30(2), 42-46.

Stăniloae, D. (2003). Ortodoxie şi națiune [Orthodoxy and nation]. In: R. Codrescu (Ed.), Fiecare in rândul cetei sale. Pentru o teologie a neamului [Each one as part of his team. For a theology of nation] (pp. 95-114). Bucharest, Romania: Christiana.

\section{Biodata}

Iuliu-Marius MORARIU - PhD. Candidate, Faculty of Orthodox Theology, "BabeşBolyai" University, Cluj-Napoca, Romania, and Associate Researcher of 
Department of Dogmatics and Christian Ethics, Faculty of Theology and Religion, University of Pretoria, South Africa. Author, coordinator of editor of 20 books and of more than 300 articles and book reviews (8 in Web of Science, 27 in Scopus), in journals of Theology and History from Romania and abroad. He graduated Faculties of Orthodox Theology and History and Philosophy from the aforementioned University, and Ecumenical Institute from Bossey, Geneva University (2017-2018), and studied in Universities from Belgrade, Kosice and Graz. 